\title{
第61回 岡山外科会
}

\author{
日 時：昭和 48 年 6 月 23 日（土） \\ 午後 1 時 午後 4 時 45 分 \\ 場 所：岡山大学医学部図書館
}

第61回岡山榊会原宏

〔昭和 49 年 3 月 14 日受稿〕

\section{1 ）水頭症に対する脳室心房, 脳室腹腔短絡術の遠隔成績}

\section{岡山大学 脳神释外科 土井 章弘松本 圭蔵}

1）昭和40年から昭和 47 年の 8 年間に38例の先天 性水頭症に脳室心房あるいは, 脳室腹腔短絡術老施 行した。遠隔死20\%であった。

physical handicapのない例又は少ない例は38例 中24例 $(63 \%)$ で有意な生活を送っている.

2)physical handicap $か ゙$ 高度な例は知能も低い.

3)脳実質の厚さ，頭囲は予後を判断する材料とは
ならない。

4) 予後を左右する最も重要な因子は術前の非可逆 的脳損儩の程度であると考えられる。

5)水頭症の治療にあたっては非可逆的脳損傷に対 しては無効であるが進行する脳損傷に対し，早期治 療, 少くとも 6 か月以内に脳室心房又は脳室腹腔短 絡術を施行すべきである.

\section{2 ) Blow-out fracture の診断と治療}

\section{岡山済生会総合病院}

昭和41年 8 月, 岡山闵生会病院に形成外科些開設 以来, 診たblow-out fracture は 6 例である.私達の 経験から診断法と治療についての要点を述へたた。

症状として眼球の上転障害に上万複視と眼窩下神 経支配域の知覚障害が最も参考之なった. 眼球宿入 は, 眼窝の腫張が強いととが多いので，早期診断に はあまり参考とならなかっった。

X線㟝断では Waters 氏法と前額断の断風撮影が

\section{形成外科 谷 大三郎宮本 義洋 吉次 興茲 二木 裕}

最も参考となった multiple fractureのとき眼窩底 の楩没があるかどうかは，X線撮影によらなければ 困難なととが多かった。

早期整復を行なったものほど，複視の消失は速か った，受傷後 1 か月半で整復した症例は，複視の消 失まで約半年を要した。

他の顔面骨折之同樣早期診断, 早期治療の重要性 を痛切に感じたしだいである。

\section{3）頭部顔面打撲でみられる Blow-out fractureについて}

川崎医科大学 脳神経外科玄 貴雄 佐藤 宏二

我々が経験したBlow-out fracture 3例を報告する. 前額, 顔面打撗後にみられろ Blow-out tracture は,
意識障害を伴う時は, 特異な眼症状より, 動眼神経 麻㾢，脳幹部挫傷と誤診されるととが少くない． 
頭部レントゲン写真は，4 方向 (Caldmell, Towne 側面（左右）を routine とし，とれに特殊撮影 (Waters, Fueger I 法,断層撮影)を撮ることにより早
期診断に努めるととが大切である。

特殊撮影として, 特に Fuege I 法が本症の診断に 有用である.

\section{4 ）非常に稀な脊揈腫瘍の 1 手術治験例}

最近, 病理組織学的に極めて稀な, 脊髄腫瘍の 1 例を経験しましたので，報告致します，患者は，16 才の男子高校生で, 右殿部から大腿にかけての疼痛を 主訴として入院しました. 諸検査の結果, 馬尾神経部 の硬膜内膸外腫場の診断で, 手術し, 長さ $7.5 \mathrm{~cm}$,

\section{倉敖成人病センター 上川 康明}

径約 $2 \mathrm{~cm}$ のソーセージ型の腫踷を摘出しました．組 織学的には,Ependymoma， myxopapillary typeで あり本邦では，極少数の報告があるのみであります. 終糸に発生したと考えられます。

\section{5）環椎前弓単独横骨折の 1 例}

\section{倉敷中央病院整形外科 黒田宏伊藤吾希夫}

22才の男子. 足場用鉄板で後頭下部を打撲し, 頚 椎過伸展障害によって惹起された環椎前弓単独横骨 折の1例を释験した. 脊髄症状はないが䅡部運動障害 が著明で，受傷時，頭を両手で支えねば起立できな かった. Cervico Pharyngeal Distance は $8 \mathrm{~mm}$
拡大していたが1ケ月後には正常值を示した。 ギプ ス床臥床 6 週後, 䅡部カラー装着. 120日で骨籍合を 認めた，極めて稀な症列であるので，外傷を伴う挿 入骨例との鑑別䛦断について述へた。

\section{6）大理石骨病の 1 例}

\section{岡大整形外科 小武守研二 藤原 紜郎}

大理石骨病は本邦においてもすでて150例以上の報 告があり, adult type は易骨折性, 疼痛をもって整 形外科を受診して発見されるてとが多い様である。

我々の経験せる患者は28才の女性で, 第 2 子出産 後より腰痛を来し，一時軽快せるも，第 3 子出産後 始まった腰痛は両下肢痛を伴って軽快せず，来診し た.レ楾所見にて，頭蓋骨，背椎，骨盤，四肢骨は
特徴ある無構造陰影を示し，臨床検査成積では，酸 性フオスフアターゼが高値を示した他は，コレステ ロール值がやや高かったのみであった。

親子兄弟全員のレ線をとっていないが，骨折を起 したり, 腰痛, 四肢痛を訴えているものはなく, 問 診では遣伝関係は否定される。

\section{7）股関節離断義足の Di agonal socket について}

$\begin{array}{rrrrr}\text { 岡山済生会総合病院 } & \text { 整形外科 永橋 } & \text { 正和 } & \text { 赤堀 } & \text { 治 } \\ & \text { 三輪 泰彦 } & \text { 安井 一夫 } & \end{array}$

岡山大学中央物療部 明石謙

M. c. Laurin らの発表したdiagonal ソケットを 我々は実際に作製し，6 例に用いて満足すべき結果
を得ている. diagonalソケットの特徽はソケットの 上縁が患側では上前骨棘の下にあり，上はバンドで 
固定していることである. このンヶットの利点とし て(1)衣服の上から目立たない，(2)通気性が良い（3) 不快感が少ない，(4)躯幹の側屈前屈が容易である.
などがあげられるままた横開きにするととによって 下腹部の圧迫感を減少し，装着を容易にしている。

\section{8）変形性䐂関節症に対する半月板切除術}

$\begin{array}{crrrr}\text { 岡山済生会総合病院 整形外科長谷川頼彦 } & \text { 赤堀 治 } \\ & \text { 高田 博 } & \text { 松村 秃樹 } & \end{array}$

40才以上の変形性膝関節症患者で, 主として半月 板に上る嵌頓症状を伴う㮦痛を訴元る30名に半月板 切除術在行い，小林の判定基準に上り秀 1 関節，優 22 関節，良 2 関節，可 1 関節，不可 2 関節，秀優あ わせて $82.2 \%$ の術後成積を得た。これより変形性膝
関節症を有する高令者でも，適応を選べば半月板切 除術は良好な結果を期待しうるが，X線上約半数に 何らかの変形性膝関節症の進行があり, 今後更に長 期の経過観察を続ける必要がある。

\section{9）血管及び神経に浸潤をきたした右大腿部平滑筋肉腫の 1 例}

\section{岡山大学 第 2 外科 江口 孝行}

血管と神経䎲浸潤をきたした右大腿平滑筋肉腫の

1 例を報告する.

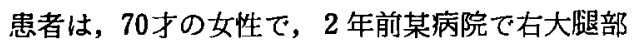
の疼痛声伴う腫瘤摘出術を受け，平滑筋肉腫と㟝断 された。しかし5ケ月前には, 再発がみられ, 腫溜 は右大腿動静脈, 神経に浸潤をきたしでいたので, 当科入入院した，手術は，右大腿部腫瘤を，大腿動

\section{内田 発三 藤村 達嘉}

静脈・神経, 筋肉の一部を含め摘出し, 動脈欠損部 には, 反対側大伏在静脈を移植した. 患者は, 術後 26 日で, 歩行障害もなく退院した。

平滑筋肉腫の発生頻度, 部位, 性別, 年合症状, 診断, 治療, 予後について考察した。

特に，その治療は，早期に広範囲に周囲組織をも 含めて摘出するととが必要であることを強調した。

\section{0）興味ある経過をたどった悪性リンパ腫の 1 例}

\section{水島第一病院 外科 小林 直広 角田 正良 竹下 篤範 水垣 伸 岡山大学 第一外科 中川潤}

我々は最近急激な病状の進行を呈し, 治療の時期 を失した悪性リンパ腫の 1 例を経験したので報告し ました，急激な貟血及びリンパ節腫脹を来たし，助 膜腔渗出夜, 腹部腫瘤を認めるも, 種々の理化学的
検查にて訩断つかず．開腹術施行するも腸問膜部に 腫瘤の主占拠部があり，成人頭大の為摘除不能閉腹 しました．以後レ線上縦隔りンパ節腫大し，入院後 6 週間にて死去しました。

\section{1）睪丸細網細胞肉腫の 1 例}

\section{岡大泌录器科 石 正臣}

\section{笠岡市民病院外科 惣路 照道}

61 才男子, 昭和 47 年 12 月初旬頃より左陰整内容篦 痛性腫大, 発熱を認めた。昭和48年 1 月10日, 笠岡

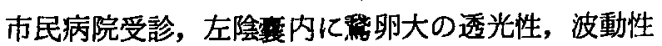

のある腫㴼を触れ，左陰襄水腫の診断の下に即日手 術施行. 約 $200 \mathrm{ml}$ の内容液排除後, 超手拳大の腫蜜を 触れ, 左高位除空術施行. 腫奮は $10 \times 5 \times 4.5 \mathrm{~cm}$, 
$110 \mathrm{~g}$. 術後, 間歇的高熱続き，11日目に死亡. 病理 組織像は睪丸細網細胞肉腫，剖検が出来なかったの
護

\section{岡大第 2 外科 多胡}

孤立性の腸骨窩鼠径部のリンパ節結核は従来より 桸とされているが（岡大第 2 外科では過去15年間に 69例の結核性リンパ節炎中 2 例約 $2.8 \%)$, 最近 39 才 の女性で鼠徍部に腫瘤があり, 左外腸骨静脈閉塞, 下
で原発か否かは不明である。
肢腫脹を来し，バザン硬結性紅斑ならびに水腎症の 傾向を来した例に腫瘤摘出を行い，良好な結果を得 た例を経験したので報告する，なお，本邦における リンパ節結核の概要についても言及する.
二木 裕

気管切開瘢痕は，縫合線の方向によってかなり 変ってくる.横方向の場合瘢痕は目立たなく, 又目立 ったとしても修正は容易である．しかし縦方向の場
合拘縮を伴った瘷痕を形成する. その洀痕形成術と しては, Z 形成術, W形成術を行うが剂果は少ない。 結論として気管切開は横に切るへききである.

\section{4) Thoracic outlet synd ome}

$$
\begin{array}{r}
\text { 岡山大第 } 2 \text { 外科 古城 昌義 } \\
\text { 越宗猪一郎 }
\end{array}
$$

Thoracic outlet syndrome は胸䂙出口において 血管神経が圧迫されておこる症候群である. 症例 1 はyperabduction syndnomeでpectoralis minor の切離術と scalenus anticusの切離術を行った. 症 例 2 はCostoclavicular syndnome で職種の変更を 行うとととして経過観察中である. Thoracic out-

\section{5）肺アスペルギローマの一例}

我々は，䓃球形成を特徵的レ線像とした肺アスペ ルギルス症の一治験例を報告する。

症例は 22 才の男性で昭和 47 年 10 月集検で胸部異常
菅田目黒 文明

勝村 達喜 寺本 滋 let syndnomeの診断のポイントは一定の肢位におけ ろ radial pulse がふれないとと,愁訴が増すととで ある. 逆行性動脈造影,プレチスモグラフも有用であ ろ. 手術として pectoralis minor 切離 scalenus anticus切離 頚肋切除 第一肋骨切除術がある.

岡山大学第2外科 土光 荘六
氏平 勝三
清水 信義
田中

陰影を発見され, 当科で右 $\mathbf{S}_{\mathbf{2}}$ の区域切除を行い略治 した. 病理学的検索により, 空洞壁には気管支構造 が見られた．又，アスペルギルスも見られた。 
16） ${ }^{169} \mathrm{Yb}$ citrateによる肺疾患のシンチグラフィー陽性描画の経験

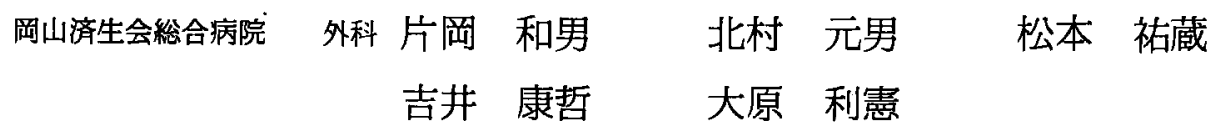

${ }^{169} \mathrm{Yb}$ citrate 使用して肺癌およひ鑑別を要す

り劣る. 肺膿煌では著明な陽性描画を示す. 従って肺 ると思われる肺疾患の陽性描画を行った30例を報告 癌と肺炎症性疾患之の鑑別診断は团難であると思わ した. 肺癌 14 例では直径 $2 \mathrm{~cm}$ 以下の 1 例を除き大体陽 れる．神経原性絴隔腫焬には取り込みは認められな 性像を示した。しかし陰影の境界はレントゲン像よ いのでてれと肺腫埕との鑑別には役立つと思われる。

\section{7）僧帽弃狭窄症に対する非直視下交連切開術の遠隔成精}

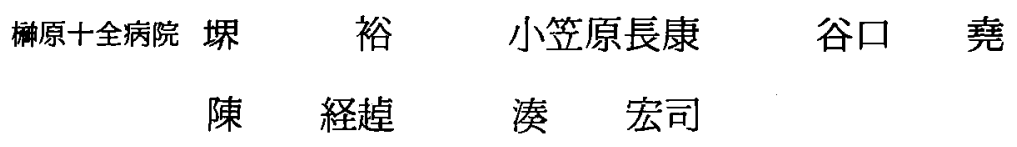

現在 僧帽弁狭窄症に対する手術術式に，非直視 下又は直視下交連切開術を行うかに論点がある. 当 院におけろ非直視下交連切開術症例287 例中,無差別 的に抽出した136例の遠隔成績を検討し,弁変形の軽
症と思われる症例で，臨床度の進行していない症例 では，非直視下交連切開術で充分手術効果を挙げ得 る事が考察された。

18）麻酔, 手術に関係した急性心筋硬塞の発生について

川崎医科大学 麻醉学教室 中條 信義 友松 栄二 中西代志夫 高折 益彦

最近日本においても，心疾患々者は増加䝨向にあ り，その増加率は米国をしのいでいる.したがって この様な患者の麻酔管理も增加し術後管理の大切さ が強調される。

我々は, 過去 1 年 4 ケ月間におこなった手術, 918
例について検討した結果，術後心筋硬塞，虚血心の 発生を 5 例経験しており,うち死亡 2 例であった. これらの患者管理上の注意点についてまとめたのて 報告する。

\section{9）食道癌と誤診した先天性短食道の治験例}

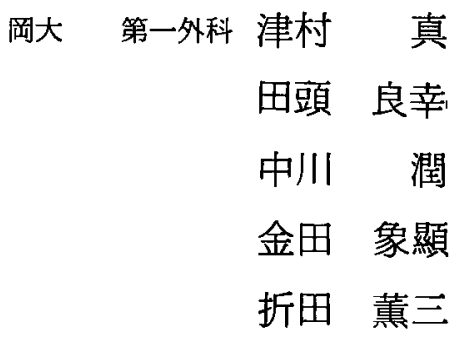

68才, 女, 悪下困難及び少量の血液が混在した嘔 吐があり, 発育障害も認められた。.X 線及び内視鏡 検查にて下部食道に悪性病変を思わせる漬煌と狭窄 を認めた. 食道癌の診断のもとに手術を施行したと
ころ, 先天性短食道であると判明した. なお, 本邦 における食道漬湯を伴った先天性短食道の報告例は 本症で第7 例目である. 


\section{0）胃癌と誤診した胃・小腸・後腹膜リンパ節結核の一症例}

$\begin{array}{rlll}\text { 岡山済生会 黒瀬 通弘 } & \text { 間野 } \text { 清志 } & \text { 広瀬 周平 } \\ \text { 青木 邦武 } & \text { 栗原 昌樹 } & \text { 大橋 勝央 }\end{array}$

症例は全身倦急感・体重減少・発熱を主訴として 来院. 臨床検査は軽度貣血と血沈の元進以外特記す るととなし．胸部レ線異常なく胃レ線にて噴門近く に腫瘤陰影を認め，GTFにて不正形の腫瘤があり 一部出血していた.以上の所見より,胃漓とそれによ
ろ後腹膜リンパ節転移と診断し開腹した. 摘出標本 の病理組織学的検查の結果胃・小腸・後腹膜リンパ 節結核であった，胃結核は稀であり，臨床的特徴が ないため, 術前診断は困難である.

\section{1）小児腹部悪性腫瘍の治療一特に合併療法の重要性について一}

\section{岡大第一外科 田㴊 勝輔 戸谷 拓二}

12年間に経験した小児腹部覀性腫場31例について 治療面より検討した。

治療成績は合併療法を行った18例之，行っていな い13例とで明らかな差がある.即ち，合併療法群の 2
年以上非再発生存例は 8 例, $44 \%$ であるが，てれの できていないグループの生存例はない．

我々の行っている合併療法の原則を示し, 特に進 行例に対する本法の意義と管理法の要点を報告した

\section{2）肝阻血とエンドトキセミア}

岡大第一外科野上 浩実 渡辺 司郎 木村 秀幸
田井 千秋

実験は肝阻血と腸管阻血を行い，時間と共にI CG の消失率をはかり，てれを肝網内系機能の指標とし た.すなわち15分の肝阻血では肝網内系機能には異 常なく,30分以上肝阻血を行う之肝網内系にirreversible な変化がおてると考えられます。

また， shock 状態下のendotoxin 含有量を調べる
と肝, 脾に少なく他の蔵器（小腸, 肺など）に多い ことがわかり, contralではendotoxin 含有量は, 肝, 脾に多いととがわかり，endotoxinは，肝網内系で 解毒されるのではないかと思われる. 従って endotoxemia 発現惹起には肝機能特に肝網内系機能の重 要性が認識されます。

\section{3）大腸の Villous tumor}

$$
\begin{array}{rrrr}
\text { 岡山大学 医学部 第一外科 中川 } & \text { 潤 } & \text { 橋本 } & \text { 修 } \\
& \text { チハバ外科 竹馬 浩 } & \text { 守山 } & \text { 稔 }
\end{array}
$$

大腸のVillous Tumor はその悪性化の問題, 組織 発生および粘液産生過剩によろ電解質喪失等の問題 に未だ不明の問題を含んでいる.

本邦では比較的稀な患者とされているが，腺腫性
ポリープとの移行型，癌の部分像としてはしばしは 経験されるものである. 我々は本疾患の3 例を経駼 したのでその組織学的特徵とその治療上の問題点に ついて若干の考察を加え報告した。 


\section{4）大腸クローン氏病の一治験例}

岡山大 第一外科橋本 修 中川 潤

最近, 消化管各部位の非特異性肉芽性炎の報告が されているが, 我々は大腸に発生したクローン氏病 を経験し，報告する．25才の未婚女性例で，下淑， 腹痛, 発熱が消長し, 回盲部に腫瘤を形成している。 大腸クローン氏病の診断で, 右半結腸切開除術, 回
晹部分切除術, 回腸横行結腸吻合術反施行し, 術後7 ケ月現在, 再発の徴候なく释過中である. 切除標本

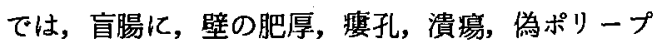
形成, 敷石状変化を認めた。

\section{5）直腸カルチノイドの一例}

$$
\text { チクバ外科竹馬浩守山 稔 }
$$

私達は肛門手術直前に施行している直晹鏡検査に て, 最近, 欧米, 本邦ともに非常に稀とされている 直腸カルチノイドの一例を経験した．患者は48才男 子で既往歴，現症に特記すへき事なく，血液，尿にも

\section{6）L－DOPA 療法と定位脳手術}

演者は1971年10月より1972年10月までの 1 年間米 国ニューヨーク大学脑神経外科に留学し, パーキン ソニズムにおける L-DOPA 療法の問題点につきとく に神経化学の面から研究する機会をえたので，その 概略を報告した，現在L-DOPA 療法においては末梢 性脱炭酸醉素抑制剂との併用により治療成績の向上 みているが,まだ副作用としてのchorea 様不随意運 動も増加している. 1 側中脳腹側被蓋野破壊による 実験的振戦有するサルを作成して, L-DOPA連続
異常を認めなかった，畽瘍のパイオプシー，特殊染 色により, 直腸カルチノィドと判明したため, 経肛 閏的に電気メスにより腫瘍のみの切除を行った，術 後，尿中 5 HIAA を椡定したが正常であった.

\section{岡山大学 脳神経外科 大本 堯史}

投与によるchorea 様不随意運動誘発し,との際の脳 内アミンの変化を検討した. L-DOPAで誘発される chorea 様異常運動は脳内ドーパミンの異常增加によ るものであり，またドーパミンニューロンを介して 惹起されると考元られたが，1 側視床腹外側核の破 壊を行なうと，対応側の振戦とともにとの異常運動 をも停止せしめることができた．また実験的脊邻損 傷における脊髄のカテコールアミンの変化について も述へた. 